\title{
Mobile Banking and its Adopting Challenges
}

\author{
Ranjini S. Nair \\ Higher College of Technology, \\ Muscat
}

\author{
Shaniba Fasal \\ Higher College of Technology, \\ Muscat
}

\begin{abstract}
Nowadays banking through mobile is vital for the individuals who are busy with their occupations furthermore for the individuals who are employed. The reason behind this study is to inspect the factors that influence the people to adopt mobile banking as the tool for their banking purpose. This observational review tried to examine the pertinence of the expansion of the eminent structure of Technology Acceptance Model (TAM) in determining the factors that influence mobile banking. Data was collected through a structured questionnaire that was distributed among different positions of people such as lecturers, students, technicians, administrative staff and the helpers in one of the college in Oman. The model was tested in a review led in this college. From the sample of 548 individuals, we applied Factor Analysis and Composite Reliability to test the reliability of the proposed model. The study findings were presented in form of tables that will reflect summary statistics .It was established that, there exists a strong, positive, and significant relationship between relative advantage and adoption of mobile banking. The empirical conclusion of this study is that the intention of the individuals to adopt mobile banking was considerably influenced by financial cost, trust, perceived risk and self-efficacy.
\end{abstract}

\section{Keywords}

mobile banking, Oman, trust, perceived risk, self-efficacy.

\section{INTRODUCTION}

Mobile Banking refers to the arrangement and benefiting of banking and financial services with the help of mobile telecommunication devices. It is the latest in a sequence of recent mobile technological wonders. Changes from applying technology in many ways have shifted the form of traditional banking transactions to mobile banking (M-banking) that emphasizes on the more convenience of customer usage[16].It offers efficient, suitable, secure and economical banking transactions. While mobile becomes a popular access point, there are many evolving benefits of mobile banking for both banks and customers. Since its introduction, mobile banking users have been able to use this added service to obtain special services $24 / 7$ without having to go physically to braches of the traditional bank for their banking services[12]. The extent of offered services may incorporate facilities to conduct bank transactions, to administer accounts and to access customized information, to transfer funds, to manage accounts. The growth of mobile banking is asserted to be as a result of technological and demographical developments that have influenced many aspects of the socio-cultural behaviour in today's world[14]. Mobile banking service can also amplify the amount of data processing and expand effective performance. Today Mobile Banking is frequently performed by means of SMS or the Mobile Internet. Special programs called "Clients Downloaded Programs" are also used to access mobile banking to their individual cell phone. Mobile banking provides great easiness to the users by releasing them from spatial and temporal limitations. It also enables them to make their payments promptly at any time. It involves great risk and uncertainty due to the lack of control. In order to use mobile banking, users need to build trust. Thus mobile service providers need to stimulate users' initial trust to maintain them. Recently, banks have also started offering applications that are accessed through the iPhone App Store, for example, providing a framework for offline use of banking web sites [15].

\section{LITERATURE REVIEW}

The Telecommunication technology has advanced to bring what is available on networked computers to mobile devices. Mobile banking offers the prospect of increasing the efficiency of the payments and potentially expanding access to financial services like banks and other financial institutions[17]. Advances in information and communication technology today have made mobile banking adoption possible in many countries as long as limitations such as lack of availability, poor wireless product quality and insufficient technology infrastructure are encountered [20].Various theories have been exhibited to investigate factors that affect an individual's acceptance towards using mobile banking. The main objective of this research is to recognize, explore and disclose factors that influence consumers' use and acceptance of mobile banking. This research also includes reviews of consumers' attitude and factors related with customers' adoption of mobile banking literature. According to Palani and Yasodha education, gender and income play an important role in shaping customer's perceptions about mobile banking services offered by Indian Overseas Bank[19].

Among numerous theories, the technology acceptance model (TAM) was considered to be the most influential and valid model for describing an individual's acceptance of information systems[1]. This study is based on the Technology Acceptance Model (TAM, 1993) which was originally proposed by Fred Davis in 1985. Additionally, it can be stated that TAM was created to explain and predict IT usage behaviour and suggests specific components of attitudes related to IT usage[18]. The technology acceptance model (TAM) explains user acceptance of a technology based on user perception[1]. Perceived usefulness (PU) and perceived ease of use (PE) are inspected in the relationship between external variables and the intention of system usage. Derived from the Theory of Reasoned Action (TRA)[2] which posits that human behavioural intention is affected by attitude and subjective norm, TAM is specialized for the use of information systems.

While PU is defined as "the degree to which a person believes that using a particular system would enhance his or her job performance," PE is defined as "the degree to which using the technology will be free of effort” (Davis, 1986, 1989).

\section{HYPOTHESIS}

The objective of this paper is to explore the variables that affect the users' acceptance of mobile banking, by considering randomly selected members from an educational institution in Oman. With reference to Venkatesh and Davis[3], we begin our hypothesis with the TAM and extended the original theory 
by including the additional variables such as perceived $\operatorname{risk}(\mathrm{PR}), \quad \operatorname{trust}(\mathrm{TU}), \quad$ self-efficacy(SE) and facilitating conditions(FC). The proposed model is given below. (refer figure 1)

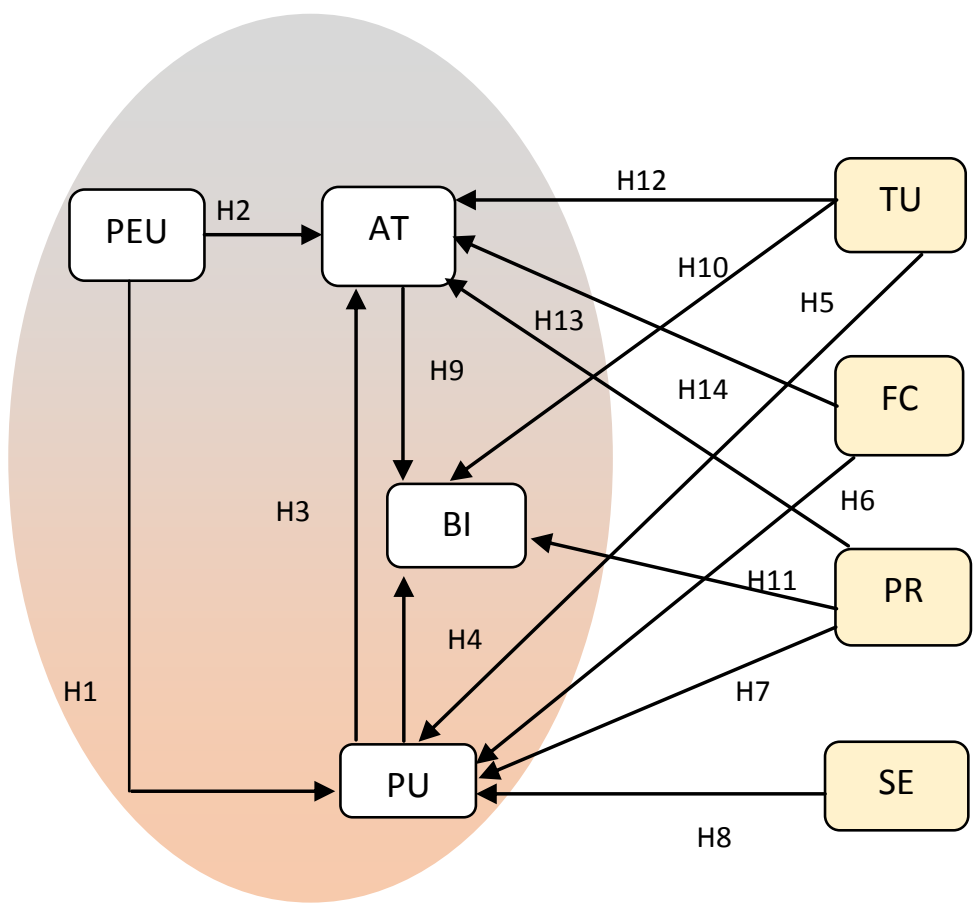

Figure 1: Proposed Research Model

\subsection{Perceived Usefulness}

$\mathrm{PU}$ is one of the independent constructs in the Technology Acceptance Model (TAM). It is "the degree to which a person believes that using a particular system would enhance his/her job performance"[1].Perceived usefulness has a positive effect on the individual's attitude and intention to use the mobile banking. Accordingly we have the following hypothesis.

H3: Attitude to use mobile banking is significantly affected by perceived usefulness.

H1: Perceived usefulness is significantly affected by perceived ease of use.

$\mathrm{H} 2$ : Attitude to use mobile banking is significantly affected by perceived ease of use.

\section{Attitude}

Attitude states an individual's sure or unsure evaluative impact about executing a particular behaviour. According to previous empirical studies have shown the existence of such generalize attitude and its influences on the evaluation of new technology[5,6,7,8]. Attitude of an individual has a positive effect on their intention to use mobile banking. The related hypothesis is given below.

H9: Intention to use mobile banking is significantly affected by attitude.

\section{Trust}

According to Pavlou "trust in e-commerce is the belief that allows consumers to willingly become vulnerable to the online retailers after having considering the retailers' characteristics" including goodwill trust (benevolence) and credibility (honesty, reliability, and integrity)[9]. In this review, by trust we mention to the security in mobile transactions and the
$\mathrm{H} 4$ : Intention to use mobile banking is significantly affected by perceived usefulness

\subsection{Perceived ease of use}

Perceived ease of use (PEU) refers to "the degree to which the prospective user expects the target system to be free of effort" [1]. According to Lau [4], concluded that perceived ease of use was significantly correlated with intention towards using the online trading system. Perceived ease of use positively affects the individual's usefulness and thus the attitude to use mobile banking. Accordingly we present the given hypothesis. secrecy of individual information. Trust has a positive effect on the perceived usefulness, attitude and the individual's intention to use mobile banking. Therefore, the following hypotheses can be stated:

H5: Perceived usefulness is significantly affected by trust.

H10: Intention to use mobile banking is significantly affected by trust.

H12: Attitude to use mobile banking is significantly affected by trust.

\subsection{Perceived Risk}

According to Bauer all behaviour of consumer could result in uncertain consequences which cannot be foreseen by themselves, and some of the consequences is likely to be unpleasant, therefore consumer behaviour involves risk from this sense [10]. Perceived risk provides a convincing analysis framework which explains consumers' intention to use mobile banking service. Perceived risk positively affects the perceived usefulness and the behavioural intention of the individual to use mobile banking, but it negatively affects their attitude. Hence the following hypothesis is put forth: 
H7: Perceived usefulness is significantly affected by perceived risk.

H11: Intention to use mobile banking is significantly affected by perceived risk.

H14: Attitude to use mobile banking is significantly affected by perceived risk.

\section{Self-Efficacy}

Compeau and Higgins defined self-efficacy as the belief that one has the capability to perform a particular function [1]. In mobile banking, perceived self-efficacy can be defined as the decision of individual's ability to use mobile banking. Users are probably to accept mobile banking when they have the capability to use it. Self-efficacy has a positive effect on Perceived usefulness. Thus, the following hypothesis holds:

H8: Perceived usefulness is significantly affected by selfefficacy.

\section{Facilitating Condition}

Facilitating conditions is defined as the degree to which an individual believes that an organizational and technical infrastructure exists to support technology use [12]. Yu empirically identified that facilitating conditions is a determinant of mobile banking intention and usage behaviour [13].Facilitating condition positively affects the perceived usefulness and attitude to use mobile banking. Considering this concept into account, the next hypothesis is:

H6: Perceived usefulness is significantly affected by facilitating condition.

H13: Attitude to use mobile banking is significantly affected by facilitating condition.

\section{Behavioural intention}

Fishbein and Ajzen [2] first defined the term "Behavioural Intention" to depict "a person's subjective probability that he will per-form some behaviour". Behavioural Intention to use is defined as a measure of the likelihood that a person will adopt the application, whereas the TAM uses actual usage to represent a self-report measure of time or frequency of adopting the application[1].Among the respondents

\section{DATA ANALYSIS AND FINDINGS}

Our research framework comprehensively reveals the demographic survey results which comprise gender, age group, educational level, income level and occupation. There were two sections for the questionnaire - sections A and B. Section A bring about the demographic information.

\subsection{Demographic findings}

In our study, data collection was done by survey method. Using a random sample, the questionnaire was distributed among a population of 600 from which 575 were collected back. After excluding the 27 incomplete questionnaires, we had a sample size of 548 .

The depiction based on the gender and age was relatively satisfactory (refer figure 2).

Our study also included the respondent's educational level. Among the respondents 15\% were under graduates (UG), 32\% were graduates and 53\% were post graduates (PG). Our study disclosed that even if education was a key factor for adopting mobile banking, under graduates were also implementing the same in their daily life(refer figure 3 ).

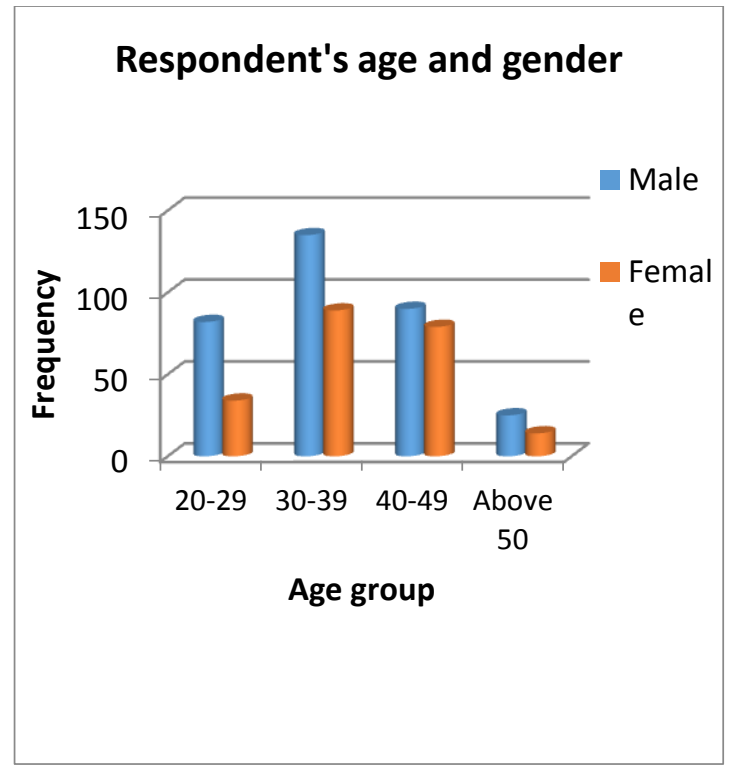

Figure: 2

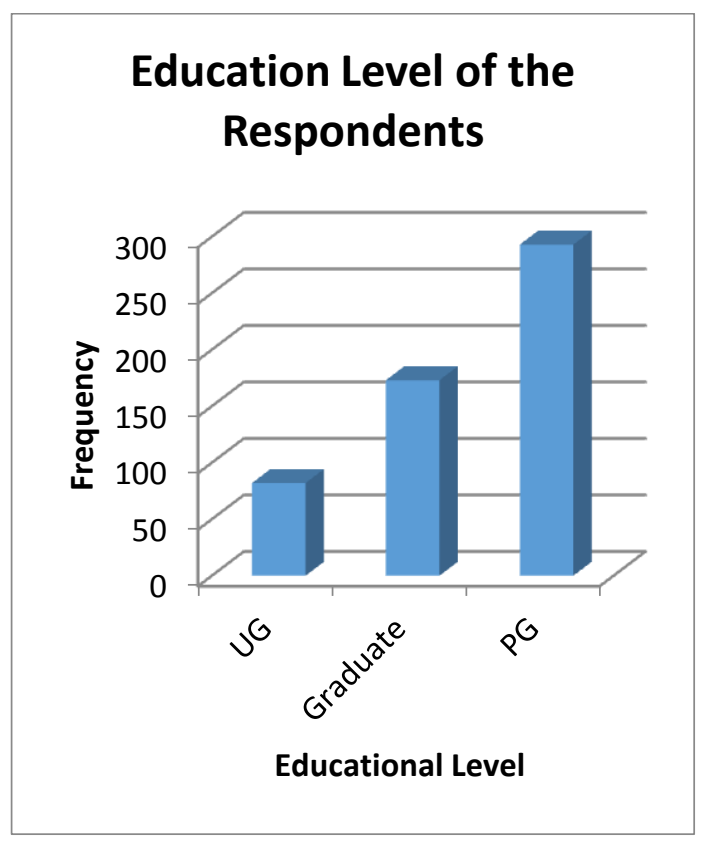

Figure: 3

The data collected was analysed and the figure 4 highlights the usage of mobile banking among the respondent's occupation.

The analysed monthly income level of the respondents is as follows: Out of the 548 respondents, $9 \%$ has an income level of less than 100 OMR. The income level of $19 \%$ was between 100-499 OMR. The third group consists of 33\% with an income level of 500-999 OMR. The largest groups of the respondents with $35 \%$ has an earnings of 1000-1499 OMR and the smallest group with $4 \%$ has an income above 1499 OMR(refer figure 5) 


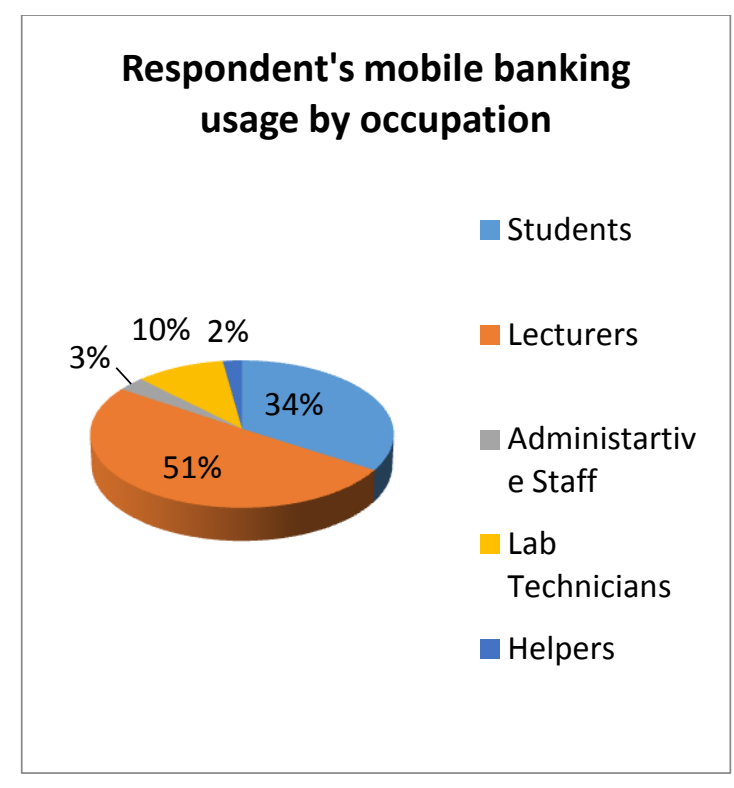

Figure: 4
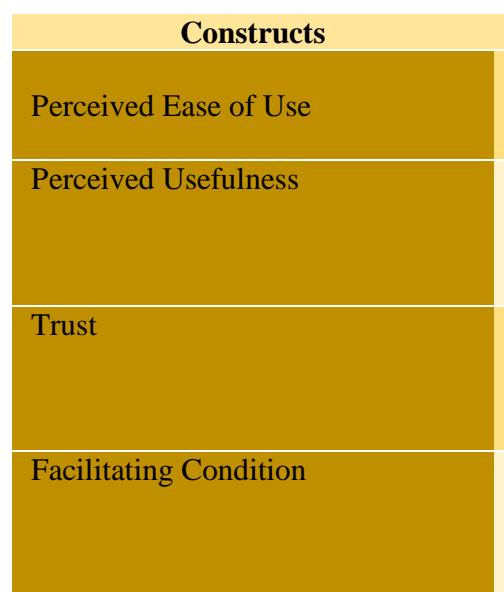

Perceived Risk

Self-Efficacy

Behavioural Intention

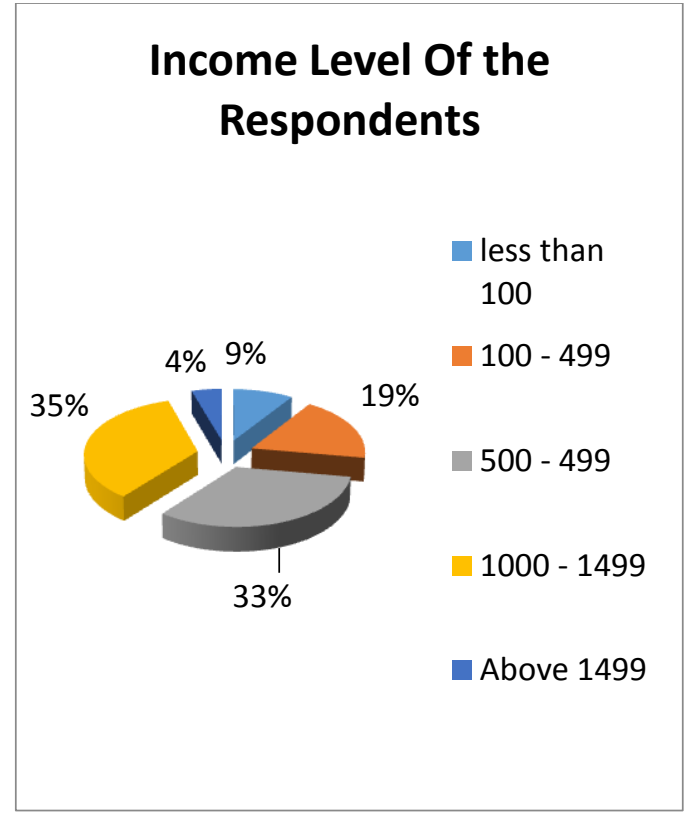

Figure: 5

\subsection{Questionnaire design}

Section B of the questionnaire for the different constructs was validated using a 5-point Likert-scale.. The statements were modified to match the context of this study related to $\mathrm{m}$ banking (refer table 1).

Using Microsoft excel the data was imported into SPSS software for statistical analysis. For measuring the accuracy of data, reliability test was conducted.

Table 1 : Constructs and corresponding Items

(PEU1) Learning to use Mobile Banking is easy.

(PEU2) It is easy to perform the steps required to use mobile payment service.

(PEU3) Interaction with Mobile Banking is easy.

(PU1) Using Mobile Banking would save my time.

(PU2) Mobile Banking can be used at any time.

(PU3) Mobile Banking can be used at any place.

(PU4) Mobile Banking allows to make all payments quicker.

(TU1) Mobile Banking is safe to use.

(TU2) All the personal information of the users are confidential.

(TU3) All transactions of the users are safe

(TU4) Mobile Banking is reliable.

(FC1) Help facility is available.

(FC2) Mobile Banking provides feedback and complaints facility.

(FC3) Customer care facility is available.

(FC4) Mobile Banking provides online offers and shopping experiences.

(PR1) Other people may access my account.

(PR2) It is easy to hack an account since the user has access to social media sites through the same gadget.

(PR3) User can lose money due to minor mistakes such as entering the wrong number or amount during money transaction.

(PR4) The Bank will not compensate the user's lose if there is any transactional error occurs.

(SE1) I have enough knowledge to use mobile Banking

(SE2) It is easy to do whatever I want to do

(SE3) It is easy to become skilful in Mobile Banking.

(BE1) User prefers to use Mobile banking for payments such as electricity bill, water bill, school fee, etc.

(BE2) User prefers to use Mobile Banking for fund transfer. 
(BE3) User prefers to use Mobile Banking for online shopping.

(BE4) User would like to use Mobile Banking in future.

(AT1) Using Mobile Banking is a good idea.

(AT2) It is beneficial to use Mobile Banking).

(AT3) I am enjoying Mobile Banking since I am able to do multiple jobs at a time.

\section{RESULT}

The current study, investigates the adoption of mobile banking among a group of peoples using TAM. Reliability assessment was done by Composite reliability test. Statistical Package for Social Sciences (SPSS) version 21 was used to conduct reliability assessment in our study. All measures which are above 0.9 demonstrate a high state of dependability, and which are between 0.7 to 0.9 has agreeable estimation dependability. As all the reliability measures crossed 0.7 , this study is viewed as dependable.

Table 2 : Factor loading and Composite Reliability

\begin{tabular}{|c|c|c|c|}
\hline Constructs & Items & Factor Loading & Composite Reliability \\
\hline Perceived Ease of Use & $\begin{array}{l}\text { PEU1 } \\
\text { PEU2 } \\
\text { PEU3 }\end{array}$ & $\begin{array}{l}0.768 \\
0.801 \\
0.732\end{array}$ & 0.705 \\
\hline Perceived Usefulness & $\begin{array}{l}\text { PU1 } \\
\text { PU2 } \\
\text { PU3 } \\
\text { PU4 }\end{array}$ & $\begin{array}{l}0.909 \\
0.875 \\
0.870 \\
0.897\end{array}$ & 0.921 \\
\hline Trust & $\begin{array}{l}\text { TU1 } \\
\text { TU2 } \\
\text { TU3 } \\
\text { TU4 }\end{array}$ & $\begin{array}{l}0.803 \\
0.753 \\
0.833 \\
0.748\end{array}$ & 0.721 \\
\hline Facilitating Condition & $\begin{array}{l}\text { FC1 } \\
\text { FC2 } \\
\text { FC3 } \\
\text { FC4 }\end{array}$ & $\begin{array}{l}0.961 \\
0.929 \\
0.834 \\
0.789\end{array}$ & 0.877 \\
\hline Perceived Risk & $\begin{array}{l}\text { PR1 } \\
\text { PR2 } \\
\text { PR3 } \\
\text { PR4 }\end{array}$ & $\begin{array}{l}0.732 \\
0.728 \\
0.735 \\
0.754\end{array}$ & 0.823 \\
\hline Self-Efficacy & $\begin{array}{l}\text { SE1 } \\
\text { SE2 } \\
\text { SE3 }\end{array}$ & $\begin{array}{l}0.880 \\
0.844 \\
0.807\end{array}$ & 0.901 \\
\hline Behavioural Intention & $\begin{array}{l}\text { BE1 } \\
\text { BE2 } \\
\text { BE3 } \\
\text { BE4 }\end{array}$ & $\begin{array}{l}0.794 \\
0.789 \\
0.791 \\
0.778\end{array}$ & 0.846 \\
\hline Attitude & $\begin{array}{l}\text { AT1 } \\
\text { AT2 } \\
\text { AT3 }\end{array}$ & $\begin{array}{l}0.882 \\
0.892 \\
0.876\end{array}$ & 0.892 \\
\hline
\end{tabular}

Table 3 depicts the standard estimates and $\mathrm{p}$ value. Perceived ease of use has a significant effect on perceived usefulness to adopt mobile banking and hence $\mathrm{H} 1$ is supported with $\mathrm{p}<$ 0.05.Perceived usefulness has a major effect on attitude and behavioural intention to use mobile banking and hence $\mathrm{H} 3$ and $\mathrm{H} 4$ are supported with $\mathrm{p}<0.05$. Perceived usefulness, behavioural intention and attitude are significantly affected by trust to adopt mobile banking and therefore the hypothesis $\mathrm{H} 5$, $\mathrm{H} 10, \mathrm{H} 12$ are supported with $\mathrm{p}<0.001$. The significant effect of perceived risk on perceived usefulness and behavioural intention to use mobile banking supports $\mathrm{H} 7$ with $\mathrm{p}<0.001$ and H11 with $\mathrm{p}<0.05$.

Also self-efficacy has a significant effect on perceived usefulness providing support for $\mathrm{H} 8$ with $\mathrm{p}<0.05$. Similarly facilitating condition has a significant effect on perceived usefulness and attitude to use mobile banking supporting H6 and H13 with $\mathrm{p}<0.05$. Due to insignificant $\beta$ value ,the hypothesis $\mathrm{H} 2$ and $\mathrm{H} 14$ are not supported and hence rejected(refer table 3 )

Table 3: Hypothesis Test

\begin{tabular}{|c|c|c|c|c|}
\hline \multicolumn{2}{|c|}{ Hypothesis } & $\boldsymbol{\beta}$ & $\mathbf{p}$ & STATUS \\
\hline $\mathrm{H} 1$ & PEU $\rightarrow$ PU & 0.213 & 0.005 & Supported \\
\hline $\mathrm{H} 2$ & PEU $\rightarrow$ AT & 0.065 & 0.265 & Not Supported \\
\hline H3 & PU $\rightarrow$ AT & 0.342 & 0.007 & Supported \\
\hline
\end{tabular}




\begin{tabular}{|c|c|c|c|c|}
\hline H4 & PU $\rightarrow$ BI & 0.314 & 0.043 & Supported \\
\hline H5 & TU $\rightarrow$ PU & 0.287 & $* * *$ & Supported \\
\hline H6 & FC $\rightarrow$ PU & 0.346 & 0.034 & Supported \\
\hline H7 & PR $\rightarrow$ PU & 0.286 & $* * *$ & Supported \\
\hline H8 & SE $\rightarrow$ PU & 0.772 & 0.007 & Supported \\
\hline H9 & AT $\rightarrow$ BI & 0.567 & $* * *$ & Supported \\
\hline H10 & TU $\rightarrow$ BI & 0.724 & $* * *$ & Supported \\
\hline H11 & PR $\rightarrow$ BI & 0.671 & 0.004 & Supported \\
\hline H12 & TU $\rightarrow$ AT & 0.458 & $* * *$ & Supported \\
\hline H13 & FC $\rightarrow$ AT & 0.821 & 0.021 & Supported \\
\hline H14 & PR $\rightarrow$ AT & -0.085 & 0.095 & Not Supported \\
\hline
\end{tabular}

\section{CONCLUSION AND DISCUSSION}

The results provided in the existing literature, suggest that TAM have the best facility to foresee and to clarify the behavioural intentions of individuals as well as customers' perceptions on the use of a new technology system-mobile banking, and information system. The focal concentration of this study was to explore customer's view of mobile banking and to examine contributory elements that impact the utilization of mobile banking in Oman. In our study we attempted to discover the factors that influence a particular group of people to adopt mobile banking for their banking transactions. From our study we concluded that the intention to use mobile banking was effected by perceived usefulness, attitude, trust and perceived risk. Since the study was conducted for a small group in a particular college in Oman, it is suggested that the same study should be conducted in a different group in a different time frame to obtain more reliable data.

\section{REFERENCES}

[1] Davis, F. D. (1989). Perceived usefulness, perceived ease of use, and user acceptance of information technology. MIS Quarterly, 13(3), 319-340.

[2] Fishbein, M., \& Ajzen, I. (1975). Belief, attitude, intention and behavior: An introduction to theory and research. MA: Addison-Wesley Reading.

[3] Venkatesh, V., and Davis, F. D. A theoretical extension of the technology acceptance model: four longitudinal field studies. Management Science, 46, 2, 2000, 186204.

[4] Lau, A. S. M. (2002). Strategies to motivate brokers adopting on-line trading in Hong Kong financial market. Review of Pacific Basin Financial Markets and Policies, 5(4), 471-489. doi:10.1142/S0219091502000894

[5] Moon, J.-W., \& Kim, Y. G. (2001). Extending the TAM for a World-Wide-Web context. Information \& Management, 38(4), 217-230.

[6] Norazah, M. S., \& Norbayah, M. S. (2009). Exploring the relationship between perceived usefulness, perceived ease of use, perceived enjoyment, attitude and subscribers' intention towards using $3 \mathrm{G}$ mobile service. Internet Journal, 3(3), 1-11
[7] O'Cass, A., \& Fenech, T. (2003). Web retailing adoption: Exploring the nature of internet users Web retailing behavior. Journal of Retailing and Consumer Services, 10(2), 81-94

[8] Vijayasarathy, L. R. (2004). Predicting consumer intentions to use on-line shopping: The case for an augmented technology acceptance model. Information \& Management, 41(6), 747-762

[9] Pavlou, P. (2003). Consumer acceptance of electronic commerce: Integrating trust and risk with the technology acceptance model. International Journal of Electronic Commerce, 7(3), 101-134.

[10]Bauer, "Consumer Behavior as Risk Taking," Proc AmerMarkAssoc, 1960, pp. 389-398.

[11] Compeau, D.R., and Higgins, C.A. (1995). Computer self-efficacy: Development of a measure and initial test. MIS Quarterly, 19(2), 189-211.

[12] Venkatesh, V., Morris, M. G., Davis, G. B. and Davis, F. D. (2003), "User acceptance of information technology: Toward a unified view", MISQuarterly, Vol.27, No.3, pp.425-478.

[13] Yu, C. (2012), "Factors affecting individuals to adopt mobile banking: Empirical evidence from the UTAUT model", Journal of Electronic Commerce Research, Vol.13, No.2, pp.104-121.

[14] Tiwari, R., \& Buse, S. (2007). The mobile commerce prospects: A strategic analysis of opportunities in the banking sector. Hamburg: Hamburg University Press

[15] Banks, J. (2009), "Mobile banking: fluid finance", Future Banking, No. 2, available at: www. bankinggateway.com/editorial/09-

02/FBA006_036_Deutsche\%20Bank.pdf (accessed 18 January 2010).

[16] R.-A. Shang, Y.-C. Chen, and L. Shen, "Extrinsic versus intrinsic motivations for consumers to shop on-line," Information and Management, vol. 42, pp. 401-413, 2005.

[17] PORTEOUS, D. 2006. The enabling environment for mobile banking in Africa. Boston: Department for International Development (DFID). 
International Journal of Computer Applications (0975 - 8887)

Volume 160 - No 4, February 2017

[18] POLATOGLU, V.N. \& EKIN, S. 2001. An empirical investigation of Turkish consumer acceptance of internet banking services. International Journal of Bank Marketing, 19(4): 156-165.

[19] Palani, A. and Yasodha, P. (2012), “A study on customer perception towards mobile banking in Indian Overseas
Bank Chennai", International Journal of Marketing and Technology, Vol. 2 No. 4, pp. 262-276

[20] World Bank (2009), “The infinite potential of mobile banking”, available at: http://blogs worldbank.org/psd/the-infinite-potential-of-mobilebanking 